\title{
Challenges of NYSC Community Development Service: Empirical Evidences from Southwestern Nigeria
}

\author{
Kazeem Oyedele Lamidi ${ }^{1}$, Kunle Sehinde Benson ${ }^{2} \&$ Ademola Lateef Adisa $^{3}$ \\ ${ }^{1}$ Department of Local Government Studies, Faculty of Administration, Obafemi Awolowo University, Ile-Ife, \\ Nigeria \\ ${ }^{2}$ Department of Public Administration, Faculty of Administration, Obafemi Awolowo University, Ile-Ife, Nigeria \\ ${ }^{3}$ Department of Sociology and Anthropology, Faculty of Social Sciences, Obafemi Awolowo University, Ile-Ife, \\ Nigeria \\ Correspondence: Kazeem Oyedele Lamidi, Department of Local Government Studies, Faculty of Administration, \\ Obafemi Awolowo University, Ile-Ife, Nigeria. Tel: 234-70-6625-2657. E-mail: akandekande@gmail.com
}

Received: June 6, 2016

doi:10.5539/jsd.v11n1p13
Accepted: June 27, $2016 \quad$ Online Published: January 4, 2018

URL: https://doi.org/10.5539/jsd.v11n1p13

\begin{abstract}
Community development service is one of the cardinal programmes of NYSC sheme. However, it appears to be one of the challenging aspects of NYSC Scheme. This study therefore analysed challenges confronting NYSC scheme in the delivery of community development service in Southwestern Nigeria. Data were obtained from both primary and secondary sources. This study concluded that poor financing $(65.4 \%)$, Lack of good ideas (67.8\%), inadequate sensitization on NYSC community development service operations/functions $(68.5 \%)$, lack of operational facilities $(76.7 \%)$, lack of motivation/incentive by the CDS coordinators $(65.4 \%)$ as well as leadership problem $(80.9 \%)$ were the identified challenges confronting NYSC scheme in the delivery of community development service within the study area.
\end{abstract}

Keywords: NYSC scheme, community development service, and NYSC community development service

\section{Introduction}

The position of youth policies and programmes appeared not to be nationalistic before independence. Not until the Gowon regime, in 1973, introduced the National Youth Service Corps Scheme (Agumagu, Adesope \& Mattew-Njoku, 2006) mainly with a view to foster the spirit of oneness and selfless service to the diverse communities - this scheme is the fulcrum around which this study revolves.

In Nigeria, It has been, most often, argued that there is no aspect of the economic, social and cultural life the NYSC Scheme has failed to contribute meaningfully (Bamidele, 1998). Specifically, this scheme offers many graduates an entry point into the labour market. Many dedicated corps members have been offered employment in their places of primary assignment (Ademowo, 2007). These are graduates who would ordinarily have roamed the streets unemployed and ignorant of the opportunities that exist in other parts of the country (World Bank, $2003 \& 2010)$.

In addition, there are communities that have benefited from the scheme through services rendered by corps members, some of which may not have been provided by either government or private intervention. The same is the case in urban centres where financial institutions, industries and the petroleum sector also tap from their expertise (Udende \& Salau, 2013). The national youth service corps scheme is indeed a channel for national unity and socio-economic development especially with the provision and availability of adequate facilities that will aid functionality and engender competitiveness among prospective corps members and not just persuasive and mandatory concept as it is today.

It is paramount to re-affirm that the significance of the community development service of the scheme in harnessing the nation's economy/abundant resources especially in rural areas of the country (Ademowo, 2007). However, preliminary interviews with some former and current corps members revealed that among all the programmes of the NYSC Scheme, the community development service was/is the most exciting, interesting and challenging aspect of the scheme. This informs that there is need for analytical examination of the challenges confronting NYSC community development service using Southwestern Nigeria as a case study. 


\section{Review of Existing Literatures}

Most of these organizations and movements are formed to solve the most pressing problems facing man in the urban environment. Perhaps, the most common and more documented of these urban social movements are those found in slum and squatter areas whose residents, through their common problems come together, find a basis for common action and form an organization (Aina, 1990). According to Ndekwu (1992) and Toyobo \& Muili (2008), the financing of development projects is often the principal constraint to community development. The constraint appears to be more predominant on the public sector at local level than private, since in many cases, according to him, the public physical developer primarily engages in the activities to produce services for which prices may not be paid. Even when prices are paid for the services resulting from the physical development, these may be lower than market prices (Fatimehin, 1992).

Aiyenigba (1992) and Okoye (1987) studies focused essentially on rural areas and rural development. Their studies indicated that there was complete absence of social service infrastructure in the development schemes of both government and NGOs, which touch directly on the welfare of the rural dwellers. The reasons for this were as a result of the misconception of rural or community development as the provision of recreational services solely for comfort of rural based weekenders, the lack of guidance offered by the government to the organizations in the most rational use of their resources and the non-realization that the welfare of the permanent resident population of rural areas is central to the concept and process of rural development (Okoye, 1987). A study was also conducted by the center for African Settlement Studies and Development (CASSAD, 1992) to evaluate the potentials of NGOs as vehicles for social and economic development in Abeokuta, Ibadan and Port Harcourt all of which are state capitals.

Studies made comparison on the characteristics, structure and mode of operation of identified development projects in the three cities. Some variables such as mode of selection of offices, keeping of records of the association, the democratic process of decision making, membership involvement in organizational activities, regularity at meetings, resource level of the organization, projects of the associations, impact assessment on members and the community at large among other attributes were scored and ranked (Toyobo \& Muili, 2008). As revealed, there is lack of community support towards these variables which strategically hindered the execution of community development projects.

Furthermore, it could be deduced from researches conducted by Obadare (2005), Toyobo \& Muili (2008), Agumagu, et al, (2006), and Adesope, et al (2013) that institutional factors impede organizational efficiency in the delivery of community development service. These include: Poor management of finance; Lack of good ideas is a major constraints to community development service operation; Lack of operational facilities; Inadequate sensitization on community development service operations/Functions; Money consciousness among the group leaders; Problem of leadership/mode of leadership structure/setup; Lack of motivation/incentive by the community development service coordinators; Lack of interest by corps members; Too many lines of action / project to be executed; Inadequate monitoring team by NYSC officers; and Lack of understanding among group members, among others.

The findings may not be applicable to all the different Local Government Areas in Nigeria. Further studies should expand the scope, according to Onibokun (1992) to include rural-based and intermediate cities Local Government Areas. In Nigeria, the provision of basic infrastructural facilities has not kept pace with the rapidly growing urban population (Agboola, 2004). The inadequacy of government to make provision in respect to the growing population has led to the adoption of self - governing techniques by the people through collective action known as Community - based organization or Non - Governmental Organization, which arises as a result of the need of the people to be met. Here, people organize themselves based on appropriate institutional arrangement; mutual agreement and shared understanding to plan and execute public goods and services that directly touch their lives (Ostrom, 1990). Participation is seen as developmental, educative and integrative and as a means of protecting freedom (Robert, 2004). Since the main assumptions of community participation is that local residents will be more supportive of the projects and therefore increase the likelihood of its success.

\section{Area of the Study}

This study was carried out in Southwestern Nigeria. The justification for choosing this region is because it is relatively homogenous. This geo-political zone comprises of six states, namely: Lagos, Ogun, Oyo, Osun, Ondo and Ekiti states. It is majorly a Yoruba speaking area, although there are different dialects even within the same state. Lagos state was created on May $27^{\text {th }}$, 1967. It was the capital of Nigeria until 1976. It has three senatorial districts, namely: Lagos Central, Lagos East and Lagos West. It has 57 Local Government Areas. Ogun state is geographically close to Lagos state; it was created in 1976 and hosts 20 Local Government Areas with three 
senatorial districts, namely: Ogun Central, Ogun East and Ogun West. Oyo state is an inland state in Southwestern Nigeria established in 1976, with its capital in Ibadan. It has 3 senatorial districts with 33 Local Government Areas. Osun state is also an inland state which was spilt off Oyo state in 1991 and hosts 30 Local Government Areas plus 1 Area Council which are demarcated in its 3 senatorial districts. Also, Ondo state was created in 1976 with its headquarters at Akure. It has 18 Local Government Areas which are divided into 3 senatorial districts. Finally, Ekiti state was carved out from Ondo states in 1996 with 3 senatorial districts and 16 Local Government Areas.

Southwestern Nigeria was stratified into three axes, namely: Lagos/Ogun states, due to their closeness and proximity; Oyo/Osun states, owing to the fact that Osun state was spilt off Oyo state; and Ondo/Ekiti states, this is also because Ekiti state was carved from Ondo state. Ogun, Osun and Ondo states were purposively selected from the three axes respectively due to their capacity to represent each of the stratified axes. One Local Government Area (LGA) was randomly selected from each of the three senatorial districts in the three selected states, making a total of 9 LGAs representing the study area. These LGAs include: Sagamu LGA, representing Ogun Central Senatorial district; Imeko Afon LGA, representing Ogun East Senatorial district; and Yewa South LGA, representing Ogun West Senatorial district. Furthermore, in Osun state, Osun Central Senatorial district was represented by Ede South LGA; Osun West Senatorial district was represented by Ifedayo LGA; and Osun East Senatorial district was represented by Ife East LGA. In Ondo state, Akure South LGA, representing Ondo Central Senatorial district; Akoko North/East LGA, representing Ondo North Senatorial district; and Okitipupa LGA, representing Ondo South Senatorial district.

\section{Methods and Materials}

Primary and secondary data were utilized for this study. Primary data were collected through the administration of questionnaire and conduct of in-depth interviews. Multi-stage sampling technique was used to select 9 LGAs in Southwestern Nigeria. The study population of 1,620 comprised senior officers on GL. 12 and above in: Works (193); Community Development (201); NYSC CDUs (108); Traditional Chiefs (270); Executive Members of NYSC CDS Groups (308); and Executive Members of CDAs (540) of the selected 9 LGAs. A sample fraction of $20 \%$, making 324 respondents, was selected for questionnaire administration from the study universe. In addition, interviews were conducted for 18 selected stakeholders on NYSC community development service so as to complement information collected through questionnaire administration. Secondary data on NYSC community development projects were obtained from books, academic journals, official documents such as NYSC publications, newspapers, magazines and the Internet. Data collected were analyzed using frequency, percentage and mean value.

On the materials, this study set out statements for the targetted respondents to ascertain whether those aforementioned factors in the existing literatures are, in actual terms, problematic to the effective delivery of community development service in Southwestern Nigeria. The instruments used in this study were questionnaire and interview guide. As such, the research instruments, which are questionnaire and interview guide, were subjected to scrutiny by the experts in the field and by the intellectuals in the faculty of administration, department of demography and social statistics as well as my supervisor, to critically examine its content and make necessary corrections in order to make them meaningful.

\section{Discussion of Findings}

This section analysed challenges confronting NYSC scheme in the delivery of community development service within the period under study in the study area. Using likert-scale ratings, respondents were asked to agree or disagree with 12 assertions made by the researcher on the challenges confronting NYSC scheme in the delivery of community development service within the period under study in the study area. Use differently, the mean value $\overline{(X)}$ here rates the strength of the respondents for each of the assertions set out to achieve this objective, using a decision rule as thus: $\overline{(X}>2.5)$ means agreement with the assertion; and $\overline{(X}<2.5)$ means disagreement, and such factor is not a challenging one.

As presented in Table 1, 185 (65.4\%) of the respondents strongly agreed that financing of development projects is often the principal constraint to NYSC community development service $\overline{(X}=3.43)$. This is a revelation that the execution of NYSC community development service suffers major pitfalls as a result of poor financing within the study area since 1999 till date. Also, Lack of good ideas was said to be a constraint to NYSC community development service operation $\overline{(X}=2.86)$. This was evidenced in the $67.8 \%$ agreement level with this assertion. Although, this finding seems not to be absolute as $32.2 \%$ probably saw reasons in other constraints rather than lack of good ideas. Nonetheless, though it is not absolute, but lack of good ideas remains a relative constraint to NYSC community development service operation. 
It was also maintained that there exits inadequate sensitization on NYSC community development service operations/functions. This finding was consequent upon $68.5 \%$ agreement level with the statement $\bar{X}=2.85)$. However, there was a $31.5 \%$ disagreement with this same statement. By implication, inadequate sensitization on NYSC community development service operations/functions was somewhat a challenge confronting NYSC scheme in the delivery of community development service. Also, inferences from this finding showed that there was $76.7 \%$ agreement with the assertion that there was lack of operational facilities. This was further verified by $\overline{(X}=3.08)$ which is above 2.50 mid-point. There was also a relative agreement with the assertion that money consciousness among the group leaders affect the realization of community development goals $(X=2.97)$. This result was an offshoot of $66.4 \%$ agreement level of the respondents with this assertion. Thus, it is an attitude, on the side of corps members, that impedes the successful delivery of community development service within the period under study in the study area.

Generally, leadership has been identified as one of the major problems militating against growth and development in all sectors of the economy and levels of government. In the course of this study, $80.9 \%$ of the respondents agreed that problem of leadership/mode of leadership structure/setup was identified as one of the major challenges obstructing NYSC scheme in the delivery of community development $\overline{\mathrm{X}}=3.60)$.

It was also observed that lack of motivation/incentive by the CDS coordinators could be identified as one of the challenges militating against the provision of community development service within the scope of this study $\overline{(X}$ $=2.71$ ). This observation was consequent upon $65.4 \%$ of the respondents who acknowledged that there seems to be lack of motivation/incentive by the CDS coordinators, thus discouraging the prompt actualization of the generic timeline of NYSC community development service.

In addition, lack of interest by corps members was investigated as one of the possible challenges hampering the provision of community development service. Reacting to this, $156(55.2 \%)$ of the respondents acceded to this feat, while $127(44.8 \%)$ of the respondents disagreed that there was lack of interest by corps members. The interpretation of this finding revealed that lack of interest by corps members was, but not to a very large extent, confrontational to the delivery of community development service $\bar{X}=2.62)$.

Furthermore, it was noted that there were many lines of actions in the delivery of community development service which could pose a major threat, leading to uncoordinated management of the projects. In their response, an aggregate of $52.3 \%$ of the respondents disagreed that many lines of actions in the delivery of community development service were not challenging $\overline{(X}=2.46)$. In the same vein, similar percentage of respondents also discredited the assertion that inadequate monitoring team by NYSC officers deters the delivery of community development service in the study area $\overline{(X}=2.46)$.

Poor understanding is one of the susceptible threats prone to group activities. However, 156 representing 55.1\% of the respondents also negated this position in respect to the NYSC CDS groups as it was noted that there seems not to be lack of understanding among group members $(\mathrm{X}=2.40)$. Likewise, respondents were asked to either agree or disagree on whether the poor management of finance, though in deficit, is a major challenge to the delivery of community development service in the study area within the period under study $\overline{(X}=2.78)$. Reacting to this, $173(61.1 \%)$ of the respondents agreed that poor management of finance remains a significant challenge to the delivery of community development service.

From the foregoing analysis, this study analysed challenges confronting NYSC scheme in the delivery of community development service. Suggesting each of the challenges in parenthesis: poor financing (65.4\%), Lack of good ideas $(67.8 \%)$, inadequate sensitization on NYSC community development service operations/functions (68.5\%), lack of operational facilities (76.7\%), lack of motivation/incentive by the CDS coordinators (65.4\%) as well as leadership problem (80.9\%) were notable challenges in the study area between $1999-2014$. 
Table 1. Challenges confronting NYSC scheme in the delivery of community development service within the period under study in the study area

\begin{tabular}{|c|c|c|c|c|c|c|c|c|c|}
\hline \multirow[t]{2}{*}{ VARIABLES } & \multicolumn{2}{|c|}{$\begin{array}{l}\text { STRONGLY } \\
\text { AGREE }\end{array}$} & \multicolumn{2}{|c|}{ AGREE } & \multicolumn{2}{|c|}{ DISAGREE } & \multicolumn{2}{|c|}{$\begin{array}{l}\text { STRONGLY } \\
\text { DISAGREE }\end{array}$} & \multirow{2}{*}{$\begin{array}{l}\mathbf{N}= \\
\mathbf{2 8 3} \\
\bar{X}\end{array}$} \\
\hline & $\mathrm{f}$ & $\%$ & $\mathrm{f}$ & $\%$ & $\mathrm{f}$ & $\%$ & $\mathrm{f}$ & $\%$ & \\
\hline $\begin{array}{l}\text { Financing of development projects is often the } \\
\text { principal constraint to NYSC community } \\
\text { development service }\end{array}$ & 185 & 65.4 & 56 & 19.8 & 22 & 7.8 & 20 & 7.1 & 3.43 \\
\hline $\begin{array}{l}\text { Lack of good ideas is a major constraints to } \\
\text { NYSC community development service } \\
\text { operation }\end{array}$ & 102 & 36.0 & 90 & 31.8 & 40 & 14.1 & 51 & 18.0 & 2.86 \\
\hline $\begin{array}{l}\text { There exits inadequate sensitization on NYSC } \\
\text { community development service } \\
\text { operations/Functions }\end{array}$ & 81 & 28.6 & 113 & 39.9 & 55 & 19.4 & 34 & 12.0 & 2.85 \\
\hline There is lack of operational facilities & 104 & 36.7 & 116 & 41.0 & 44 & 15.5 & 19 & 6.7 & 3.08 \\
\hline $\begin{array}{l}\text { Money consciousness among the group leaders } \\
\text { affect the realization of community } \\
\text { development goals }\end{array}$ & 104 & 36.7 & 84 & 29.7 & 77 & 27.2 & 18 & 6.4 & 2.97 \\
\hline $\begin{array}{l}\text { Problem of leadership/mode of leadership } \\
\text { structure/setup is one of the major challenges } \\
\text { obstructing NYSC scheme in the delivery of } \\
\text { community development }\end{array}$ & 133 & 46.3 & 98 & 34.6 & 54 & 19.1 & - & - & 3.60 \\
\hline $\begin{array}{l}\text { There seems to be lack of motivation/incentive } \\
\text { by the CDS coordinators }\end{array}$ & 69 & 24.4 & 116 & 41.0 & 46 & 16.3 & 52 & 18.4 & 2.71 \\
\hline There is lack of interest by corps members & 65 & 23.0 & 91 & 32.2 & 81 & 28.6 & 46 & 16.3 & 2.62 \\
\hline $\begin{array}{l}\text { There is too many lines of action / project to be } \\
\text { executed }\end{array}$ & 52 & 18.4 & 83 & 29.3 & 91 & 32.2 & 57 & 20.1 & 2.46 \\
\hline $\begin{array}{l}\text { Inadequate monitoring team by NYSC officers } \\
\text { deters the delivery of community development }\end{array}$ & 63 & 22.3 & 72 & 25.4 & 79 & 27.9 & 69 & 24.4 & 2.46 \\
\hline $\begin{array}{l}\text { There seems to be lack of understanding among } \\
\text { group members }\end{array}$ & 59 & 20.8 & 68 & 24.0 & 82 & 29.0 & 74 & 26.1 & 2.40 \\
\hline $\begin{array}{l}\text { Poor management of finance remains a } \\
\text { significant challenges to the delivery of } \\
\text { community development service }\end{array}$ & 90 & 31.8 & 83 & 29.3 & 67 & 23.7 & 43 & 15.2 & 2.78 \\
\hline
\end{tabular}

Source: Field Survey, 2015

NB: $\mathrm{f}=$ Frequency

$$
\begin{aligned}
& \%=\text { Percentage } \\
& \mathrm{X}=\text { Mean value } \\
& \mathrm{N}=\text { Total Number of Respondents }
\end{aligned}
$$

\section{Synopsis of the Interview Analysis}

To complement the data gathered through questionnaire administration, some key personalities were interviewed. Most remarkably, the 18 interviewees noted that funding is the number challenge confronting the provision of community development service in Southwestern Nigeria and the country at large. Laziness on the side of NYSC 
officials and corps members was also identified as constraints militating against the provision of community development service.

However, a State Coordinator of NYSC scheme averred that the communities themselves have failed to key into NYSC community development service. He stated that "most communities do not provide necessary supports needed by the corps members in their efforts to render needed social service for their host communities". This same statement was reechoed by a Chairman, House Committee on Community Development that "there exists sometimes lack of understanding between the corpers and their host communities".

Interview analysis on the challenges facing NYSC scheme in the provision of community development service was noted that there was lack of motivation for corpers; and similarly, there seems to be no adequate incentives for CDS coordinators who should have guided the corps members in the process and genric timeline of community development service. Lack of operational facilities as well as non-cooperation among the NYSC CDS group members were also mentioned by the majority of the interviewees.

\section{Concluding Remarks}

This study concluded that poor financing $(65.4 \%)$, Lack of good ideas $(67.8 \%)$, inadequate sensitization on NYSC community development service operations/functions (68.5\%), lack of operational facilities (76.7\%), lack of motivation/incentive by the CDS coordinators (65.4\%) as well as leadership problem (80.9\%) were the identified challenges confronting NYSC scheme in the delivery of community development service within the period under study in the study area. However, the findings of Adesope et al (2012), though presented in mean score, reflected the identified challenges confronting the delivery of community development service. In addition, Toyobo and Muili (2008) posited that Low allowance for corps members, poorly financed NYSC activities and under-utilization of serving youths were the major constraints to NYSC's effectiveness from corps members' perspectives on community development.

\section{Recommendations}

The following recommendations were offered to help the NYSC scheme resuscitate the dwindling components of NYSC community development service:

Security of lives and properties must be guaranteed so as to ascertain the willingness of graduates of tertiary institutions to participate in NYSC scheme; acceptance of postings to various communities in the nook and cranny of the country; as well as, readiness to play active role in the discharge of community development service in their communities of service.

It is also recommended that funds should be made available for individual and group projects so that meaningful activities can be carried out. Also, adequate monitoring and evaluation should be done to ensure that project funds are properly utilized. This will motivate corps members to work. Individual corpers who have personal projects to embark on would be encouraged to do so.

It is further recommended that commitment of the scheme's management and proper guidance of Corps members as well as availability of operational facilities and logistics would go a long way in tackling aforementioned challenges confronting the provision of community development service.

\section{References}

Ademowo, Y. (2007). NYSC: Exploring the Diversity in the Unity of Nigeria. Retrieved May 6, 2010, from www.nigerian-newspaper.com/national_youth_service_corps.htm

Adesope, O. M. (2007). Agricultural Youth Organization: Introductory Concept (2nd ed.). Port Harcourt: University of Port Harcourt Press.

Adesope, O. M., Jike-Wai, O., \& Opurum, L. C. (2013). Analysis of Corpers Perception and Attitude towards Community Development Service of the Nigerian NYSC in Abia State. Greener Journal of Social Sciences, 3(10), 511-518. https://doi.org/10.15580/GJSS.2013.10.082013792

Agboola, T. (Ed.). (2004). Readings in Urban and Regional Planning. Ibadan: Macmillian Publishers.

Agumagu, A. C., Adesope, O. M., \& Mathews-Njoku, E. C. (2006). Attitude of Youth Corpers towards the Community Development Service of NYSC Nigeria. Journal of Agricultural and Social Research (JASR), $6(1), 78-82$.

Aina, O. (1990). Broadening the role of National Youth Service Corps members in nation building. Address given on the occasion of the twentieth anniversary of the National Youth Service Corps in Nigeria, at Muson Centre, Onikan- Lagos. 
Aiyenigba, B. D. M. (1992). Rural Development and Sustainability: The Role of NGOs in Ijumu Local Government Area of Kogi State. Unpublished Master of Urban and Regional Planning Dissertation. Centre fo Urban and Regional Planning, University of Ibadan.

Bamidele, L. (1998). NYSC: An enduring legacy. A public lecture organized in Abuja on June 4, 1998. Retrieved November 20, 2005, from http//www.onlinenigeria.com/links/NYSC

CASSAD. (1992). Non-Governmental Organisations in Nigerian Communities: A Critical Evaluation of their Characteristic, Achievements and Potentials for Social and Economic Development. Summary of Study Report.

Fatimehin, S. O. (1992). Physical Development Project Appraisal and Management for Self-Reliance at Local Government Level. Paper presented at a National Workshop on Mobilizing Resources for Physical Development: Challenges for Local Governmen in Nigeria. NISER. Ibadan, 9th - 10th November.

Ndekwu, E. C. (1992). Financing Options for Physical Development in the Local Government Area, Paper presented at a Workshop on Mobilizing Resources for Physical Development at the Local Government Areas. NISER. Ibadan. pp. $9-10$.

Obadare, E. (2005). The Effects of National Service in Africa, with a Focus on Nigeria. A paper presented at International Symposium on Civic Service: Impacts and Inquiry, held at George Warren Brown School of Social Work, Washington University in St. Louis, Missouri, September 24-26 2005.

Okoye, J. C. (1987). Social Clubs, Resource Management and Rural Development in Nigeria: Lessons from Anambra State. Journal on Transaction Institute of British Geographers. N. S. 13. 222-227.

Onibokun, A. G. (1992). Role of Community-Based Organisations in Socio-Economic Development in Nigeria. An Address at the Opening Ceremony of a Workshop Organized by CASSAD in Collaborationswith Ford Foundation.

Ostrom, E. (1990). Governing the Commons: The Evolution of Institutions for Collective Action. New York: Cambridge University Press. https://doi.org/10.1017/CBO9780511807763

Roberts, N. (2004). Public Deliberation in an Age of Direct Citizen Participation. American Review of Public Administration, 34. https://doi.org/10.1177/0275074004269288

Toyobo, A. E., \& Muili, A. B. (2008). Constraints Militating against Effectiveness of Community Development Projects in Ilesa. Journal of Geography and Regional Planning, 1(8), 144-150.

Udende, P., \& Salau, A. A. (2013). National Youth Service Corps Scheme and the Quest for National Unity and Development: A Public Relations Perspective. Ilorin: Department of Mass Communication, University of Ilorin.

World Bank. (2003). NYSC: An Enduring Legacy. Retrieved May 6, 2010, from www.thisdayonline.com/archive/2002/10/07

World Bank. (2010). Nigeria: Country Brief. Retrieved March 7, 2012, from www.google.com $/ \mathrm{ng} /$ search?q=population $+08+$ nigeria

\section{Copyrights}

Copyright for this article is retained by the author(s), with first publication rights granted to the journal.

This is an open-access article distributed under the terms and conditions of the Creative Commons Attribution license (http://creativecommons.org/licenses/by/4.0/). 